\title{
Effect of Canal Curvature and Instrument Type on the Amount of Apically Extruded Debris
}

\author{
Kök Kanal Eğiminin ve Enstrüman Tipinin Apikalden Taşan Debris \\ Miktarına Etkisi
}

\section{Seniha MIÇOoĞULLARI KURT, İlknur KAŞIKÇI BILGI, Gözde KANDEMIR DEMIRCI, Burcu SEREFOGLU, Mehmet Kemal ÇALIŞKAN}

Ege Üniversitesi Dişhekimliği Fakültesi, Endodonti Ana Bilim Dalı, İzmir

Atıf/Citation: Miçoğulları Kurt, S., Kaşıkçı Bilgi, İ., Kandenir Demirci, G., Şerefoğlu, B., Çalışkan, M.K., (2021). Effect of Canal Curvature and Instrument Type on the Amount of Apically Extruded Debris. Ege Üniversitesi Diş Hekimliği Fakültesi Dergisi, 42(2), $115-119$.

\begin{abstract}
INTRODUCTION: The aim of this study was to evaluate the effect of the curvature on the amount of apically extruded debris caused by three NiTi systems using different kinematics via including straight and severely curved root canals.

METHODS: 84 severely curved and 84 straight mature root canals were instrumented with; Twisted File Adaptive (TFA), ProTaper Next (PTN) and WaveOne Gold (WOG) systems. The extruded debris and irrigant was collected into pre weighed glass tubes and weighed by using a 10-5 microbalance after the evaporation of irrigant. The effect of curvature on debris extrusion were analysed with $t$ test and the amount of debris extrusion between the file systems was compared with One-way ANOVA test at a 0.05 level of significance.

RESULTS: Within each file system, the amount of extruded debris was similar for curved and straight canals $(p>0.05)$. The tested instruments showed no significant differences in amount of extruded debris for both straight and curved root canals $(p>0.05)$, with the following ranking order: PTN > WOG > TFA.

DISCUSSION AND CONCLUSION: It can be concluded that all the tested instruments with different kinematics caused debris extrusion and the curvature of the root canal has no effect on apical debris extrusion.

Keywords: Debris extrusion, curved root canals, PTN, TFA, WOG

\section{Öz}

GiRiş ve AMAÇ: Bu çalışmanın amacı kök kanal eğiminin ve farkı NiTi enstrümantasyon sistemlerinin apikalden taşan debris miktarı üzerindeki etkisinin değerlendirilmesidir.

YÖNTEM ve GEREÇLER: Çalışmada kök gelişimini tamamlamış 84 adet eğimli ve 84 adet düz kök kanalı kullanıldı. Eğimli ve düz kökler kendi içlerinde 3 gruba ayrılarak, kök kanal șekillendirmeleri Twisted File Adaptive (TFA), ProTaper Next (PTN) ve WaveOne Gold (WOG) sistemleri ile gerçekleştirildi. Her sistemle uygulanan kök kanal şekillendirmesi sırasında apikalden taşan yıkama solüsyonu ve debris önceden ağırlığı belirlenmiş cam tüplere toplandı. Solüsyon buharlaştırıldıktan sonra tüpün ağırlığı 10-5 hassas tartı kullanılarak ölçüldü ve tüpün son ağırlığından ilk ağırık çıkartılarak taşan debris miktarı belirlendi. Elde edilen veriler t testi ve tek yönlü Anova testi ile değerlendirildi.

BULGULAR: Her eğe sistemi için kök kanal eğiminin taşan debris miktarı üzerinde etkisi olmadığı gözlendi $(P>0.05)$. Tüm sistemlerde debris taşması meydana geldi ve hem eğimli hem de düz köklü dişlerde sistemler arasında istatistiksel fark gözlenmedi $(P>0.05)$.

TARTIŞMA ve SONUÇ: Test edilen farklı kinematiklere sahip tüm eğe sistemlerinin debris ekstrüzyonuna neden olduğu ve kök kanal eğiminin apikal debris ekstrüzyonu üzerinde etkisinin olmadığı sonucuna varılmıştır.
\end{abstract}

Anahtar Kelimeler: Debris ekstrüzyonu, kök kanal eğimi, PTN, TFA, WOG 
KabulTarihi/Accepted Date: 05.02.2021

\section{INTRODUCTION}

The cleaning and shaping of root canals using instrumentation and irrigation procedures is generally considered the key step in eliminating microorganisms. A wide range of engine-driven nickel-titanium (NiTi) instruments with different kinematics, alloy properties, and cross-sectional designs are now an indispensable part of the shaping step. However, it has been reported that all of these systems result in debris extrusion ${ }^{1,2}$, which is known to cause postoperative symptoms, periradicular tissue reactions, and endodontic treatment failure ${ }^{3,4}$

It is important to select the most appropriate instrument type and motion to prevent or minimize extruded debris. WaveOne Gold (Dentsply Maillefer, Ballaigues, Switzerland) is a single-file system based on reciprocating motion and a parallelogram cross-section. ProTaper Next (PTN) (Dentsply Maillefer) is working with rotary motion, with an off-centred rectangular crosssection and variable taper design. The Twisted File Adaptive (TFA) system (SybronEndo, Orange, CA, USA) combines continuous rotation and reciprocation. The files use predominantly continuous rotation and when the stress on the file increases, the system changes the rotation motion to reciprocation.

Although there is extensive existing research on apical debris extrusion in straight root canals ${ }^{5-7}$, few studies have assessed this issue in relation to moderately curved cases $^{8-11}$. Moreover, to the best of the author's knowledge, only one study to date has sought to determine whether the influence of the curvature on debris extrusion differs between straight, moderate, and severely curved canals when using only a reciprocal instrument ${ }^{11}$. The aim of the present study was to compare the amounts of apically extruded debris caused by three NiTi systems using different kinematics (Twisted File Adaptive (TFA), ProTaper Next (PTN), WaveOne Gold (WOG) in both straight and severely curved root canals.

\section{MATERIALS AND METHODS}

This study was approved by the Human Ethical Committee of Ege University, School of Medicine, Izmir, Turkey (16-8/12). In line with a previous study ${ }^{12}$, an initial power analysis confirmed that a minimum sample size of 28 teeth per group is required $(80 \%$ power, $\alpha=5 \%$ ). Extracted human maxillary molar teeth with mature apices were collected, and teeth with root fractures or cracks, internal or external resorption, or calcified root canals were excluded. Mesio-buccal and disto-buccal roots were separated at furcation level.

Based on two digital radiographs taken in the buccolingual and mesio-distal directions, AutoCAD 2007 (Autodesk Inc., San Rafael, CA, USA) was used to measure root canal curvature and radius, following Pruett et al. 's ${ }^{13}$ method. Access cavities were prepared with diamond burs under water cooling, and presence of apical patency was controlled using an ISO size $10 \mathrm{~K}$-file. In total, 168 roots $\left(84\right.$ with canal curvature of $30^{\circ}-50^{\circ}$ and radii of $10-12 \mathrm{~mm}$ and 84 with curvature of $0^{\circ}-5^{\circ}$ ) were selected for the study. To ensure random allocation to the experimental groups, the curved root canals were categorized according to degree of curvature $\left(30^{\circ}-35^{\circ}\right.$, $\left.36^{\circ}-40^{\circ}, 41^{\circ}-45^{\circ}, 46^{\circ}-50^{\circ}\right)$ and, roots from each curvature category were randomly assigned to three groups $(n=28)$ based on instrument type. The extruded debris was collected using the method described by Myers \&Montgomery ${ }^{14}$.

A $10 \mathrm{~K}$-file (Mani, Tochigi Ken, Japan) was placed into root canals until the tip of the file was seen at the apical foramen, and working length (WL) was accepted as $1 \mathrm{~mm}$ short of this measurement. The buccal cusp edges of each tooth were flattened, and lengths of all teeth were standardized. For glide path preparation, $15 \mathrm{~K}$-files were used for each root canal. All files were used at a WL of $18 \mathrm{~mm}$, with an apical root canal preparation size of $25 \#$ for each group.

Group 1: TFA instruments were used at TF Adaptive mode of the Sybron Endo Elements Motor (Sybron Endo, Orange, CA, USA). The instruments were used without forcing, and the procedure was repeated up to the WL. Final apical preparation was completed with SM2 instrument (\#25.06).

Group 2: PTN files were used in PTN mode at 300 rpm and $2.5 \mathrm{Ncm}$ with an X-Smart plus motor. Files were used at WL with in and out brushing motion and root canal preparation was finished with $\mathrm{X} 2$ instrument ( \#25.06).

Group 3: WO Gold primary files ( \#25.07) were used in a slow in-and-out motion with an X-Smart Plus motor. The file was removed from the root canal after three pecking, and the process was continued until WL was reached.

All root canal instrumentation was completed by a single experienced operator, and the amount of debris was evaluated by another examiner, who was blinded to all experimental groups. During the instrumentation procedure, each root canal was irrigated with a total $9 \mathrm{~mL}$ of distilled water and a side-venting needle (30G) (Kerr Hawe Sa, Bioggio, Switzerland) was used at $2 \mathrm{~mm}$ shorter than the WL.

Extruded irrigant and debris were collected in preweighed glass tubes (Smart Kimya, İzmir, Turkey). After root canal instrumentation, the root ends of all teeth were washed with $1 \mathrm{~mL}$ of distilled water to collect debris adhering to the root end. The glass tubes were dried in a dry-heat oven (FN 120, Nüve, Ankara, Turkey) at a constant temperature of $95^{\circ} \mathrm{C}$ for 48 hours and weighed using a $10^{-5}$ microbalance (Denver Instrument $\mathrm{GmbH}$, Gottingen, Germany) after evaporation of the irrigant. 
Three measurements were taken for each tube, and mean values were calculated. The amount of extruded debris was calculated by subtracting the initial weight from the final weight.

Data were analysed using SPSS software version 17.0 (IBM SPSS Inc., Chicago, IL, USA), and the level of significance was set at 5\% for all tests. The effect of curvature on debris extrusion was analysed by Student's t-test; amount of debris extrusion for each file system was compared using one-way analysis of variance. Post hoc comparisons were performed using Student's t-test.

\section{RESULTS}

Mean values for extruded debris associated with each system are displayed in Table 1 . The results showed that, within each file system, the amount of extruded debris was similar for curved and straight canals $(p>0.05)$. The tested instruments showed no significant differences in amount of extruded debris for both straight and curved root canals $(\mathrm{p}>0.05)$, with the following ranking order: PTN $>$ WOG $>$ TFA.

Table 1: Mean amount of apically extruded debris and standard deviations (SD) after using each instruments (grams)

\begin{tabular}{|c|c|c|c|c|}
\hline \multicolumn{5}{|c|}{ Type of instrument } \\
\hline Extruded debri & s (g) & TFA & PTN & WOG \\
\hline Straight Canal & Mean (SD) & $0.000430(0.000338)$ & $0.000593(0.000608)$ & $0.000431(0.000405)$ \\
\hline Curved Canal & Mean (SD) & $0.000378(0.000298)$ & $0.000541(0.000799)$ & $0.000504(0.000367)$ \\
\hline
\end{tabular}

\section{DISCUSSION}

Apical debris extrusion may initiate an inflammatory reaction in periapical tissues, causing flare-up and longterm failure of periapical healing ${ }^{3}$. Factors such as instrumentation technique ${ }^{2,15}$, working length change, and degree of root canal curvature ${ }^{8}$ may influence debris extrusion. In most previous studies of debris extrusion, the included tooth types were not standardized, and the amount of irrigant used varied from $2 \mathrm{ml}^{16}$ to $23 \mathrm{ml}^{17}$. Tooth type standardization is an important issue, as root canal morphology and apical diameter may affect the extent of debris extrusion. For this reason, the current study aimed primarily to compare the amount of apical debris extrusion in straight $\left(<5^{\circ}\right)$ and severely curved maxillary molar teeth $\left(30^{\circ}-50^{\circ}\right.$, radius $\left.10-12 \mathrm{~mm}\right)$ by means of a standardized procedure. Additionally, as the amount of irrigant and possible crystallization of $\mathrm{NaOCl}$ may increase the amount of debris ${ }^{8,18}, 10 \mathrm{ml}$ of distilled water was used for each root canal.

Under clinical conditions, the periapical tissues may act as a physical barrier, so reducing the amount of extruded debris. In the experimental model, the absence of periapical tissues may have resulted in apical debris extrusion. Floral foam and agar gel could be used to simulate the periapical tissues, but as these materials are reportedly inadequate ${ }^{19,20}$, no attempt was made to simulate the periapical tissues in the present study.

Among the limited number of existing studies evaluating the influence of root canal curvature on amount of extruded debris ${ }^{8,11,18}$, two of these ${ }^{8,18}$ measured apical debris extrusion using slightly and moderate curved root canals and reported that root canal curvature does not affect debris extrusion. There is only one study ${ }^{11}$ that evaluated the influence of root canal curvature on amount of extruded debris in slightly, moderate, and severely curved root canals reported significantly more debris extrusion in the severely curved group than in the slightly curved group. However, that study evaluated only a reciprocal instrument (Reciproc R25). As the type and kinematics of the instrument may affect the amount of extruded debris, the current study compared three instruments using different kinematics. The results of the present study showed no significant difference between straight and severely curved canals in terms of amount of debris extrusion caused by each kinematic.

Comparing the results for the reciprocating (WOG) group with Karataşlıoğlu et al. ${ }^{11}$, similarly severely curved root canals were found to exhibit more debris extrusion than straight root canals, although the difference was not statistically significant. As the authors was declared that 'more pecking motions were needed during the preparation of the curved root canals to reach the full working length with files' ${ }^{11}$, it can be interpreted that presence of a severe curvature may have caused an increase in the amount of debris extrusion. According to Berutti et al. ${ }^{21}$, decreased canal length due to flattening of root canal curvature is another factor that may cause more apical debris extrusion when using reciprocal motion. However, this claim remains speculative, as neither Karataşlıoğlu et al. ${ }^{11}$ nor the current study examined root canal flattening. On the other hand, in the present study kinematics other than reciprocation were also evaluated and the results showed no significant difference between straight and severely curved canals in terms of amount of debris extrusion for all kinematics. There are several studies which evaluated the shaping ability of NiTi rotary and reciprocating instruments and it has been reported that both of rotary and reciprocal movements preserved the original root canal anatomy and respected the original root canal curvature ${ }^{22,23}$. Maintening the original root canal anatomy and the curvature by the instruments from each kinematics used in this study may be the reason of observing no significant difference between straight and severely 
curved canals in the amount of debris extrusion.

While the literature shows no consensus in relation to the effect of kinematics on amount of debris extrusion, some studies have reported that reciprocating motion ${ }^{24,25}$ or continuous rotary motion ${ }^{2,5}$ cause less apical debris extrusion. However, other studies found no significant difference between rotary and reciprocating systems. In their evaluation of PTN, WO, and TFA systems, Kirchhoff et al. ${ }^{15}$ found no significant difference between the instruments. Silva et al. ${ }^{17}$ also reported that the PTN and WO instruments caused similar amount of debris extrusion, and Boijink et al. ${ }^{26}$ reached the same conclusion in relation to the TFA and WOG systems. As in previous studies ${ }^{15,17,26}$, the present findings indicate no significant differences among the tested instruments for both straight and curved root canals.

\section{REFERENCES}

1. Tanalp J, Güngör T. Apical extrusion of debris: a literature review of an inherent occurrence during root canal treatment. Int Endod J 2014; 47:211-221.

2. Bürklein S, Benten S, Schäfer E. Quantitative evaluation of apically extruded debris with different single-file systems: Reciproc, F360 and OneShape versus Mtwo. Int Endod J 2014; 47:405-409.

3. Seltzer S, Naidorf IJ. Flare-ups in endodontics: I. Etiological factors. 1985. J Endod 2004; 30:476-481.

4. Siqueira JF Jr. Microbial causes of endodontic flareups. Int Endod J 2003; 36:453-463.

5. Bürklein S, Schäfer E. Apically extruded debris with reciprocating single-file and full-sequence rotary instrumentation systems. J Endod 2012; 38:850-852.

6. Capar ID, Arslan H, Akcay M, et al. An in vitro comparison of apically extruded debris and instrumentation times with ProTaper Universal, ProTaper Next, Twisted File Adaptive, and HyFlex instruments. J Endod 2014; 40:1638-1641.

7. Borges ÁH, Pereira TM, Porto AN, et al. The Influence of Cervical Preflaring on the Amount of Apically Extruded Debris after Root Canal Preparation Using Different Instrumentation Systems. J Endod 2016; 42:465-469.

8. Leonardi LE, Atlas DM, Raiden G. Apical extrusion of debris by manual and mechanical instrumentation. Braz Dent J 2007; 18:16-19.

9. Elmsallati EA, Wadachi R, Suda H. Extrusion of debris after use of rotary nickel-titanium files with different pitch: a pilot study. Aust Endod J 2009; 35:65-69.

10. De-Deus G, Neves A, Silva EJ, et al. Apically extruded dentin debris by reciprocating single-file and multi-file rotary system. Clin Oral Investig 2015; 19:357-361.

11. Karataslioglu E, Arslan H, Er G, et al. Influence of canal curvature on the amount of apically extruded debris determined by using three-dimensional determination method. Aust Endod J 2019; 45:216-224.

\section{CONCLUSION}

Based on the results of the current study, it can be concluded that while all three systems caused apical debris extrusion, kinematics and root canal curvature had no effect on apical debris extrusion. Although further investigation is needed, the results of the present study contribute to clinicians' knowledge about the effects of root canal curvature and kinematics on debris extrusion for TFA, PTN and WOG NiTi files during root canal instrumentation.

\section{Declaration of interest statement}

The authors report no conflict of interest.

12. Kaşıç̧ı Bilgi I, Köseler I, Güneri P, et al. Efficiency and apical extrusion of debris: a comparative ex vivo study of four retreatment techniques in severely curved root canals. Int Endod J 2017; 50:910-918.

13. Pruett JP, Clement DJ, Carnes DL Jr. Cyclic fatigue testing of nickel-titanium endodontic instruments. $J$ Endod 1997; 23:77-85.

14. Myers GL, Montgomery S. A comparison of weights of debris extruded apically by conventional filing and Canal Master techniques. J Endod 1991; 17:275279.

15. Kirchhoff AL, Fariniuk LF, Mello I. Apical extrusion of debris in flat-oval root canals after using different instrumentation systems. J Endod 2015; 41:237-241.

16. Tinaz AC, Alacam T, Uzun O, et al. The effect of disruption of apical constriction on periapical extrusion. $J$ Endod 2005; 31:533-535.

17. Silva EJ, Carapiá MF, Lopes RM, et al. Comparison of apically extruded debris after large apical preparations by full-sequence rotary and single-file reciprocating systems. Int Endod J 2016; 49:700705.

18. Hinrichs RE, Walker WA 3rd, Schindler WG. A comparison of amounts of apically extruded debris using handpiece-driven nickel-titanium instrument systems. J Endod 1998; 24:102-106.

19. Altundasar E, Nagas E, Uyanik O, et al. Debris and irrigant extrusion potential of 2 rotary systems and irrigation needles. Oral Surg Oral Med Oral Pathol Oral Radiol Endod 2011; 112: 31-5.

20. Lu Y, Wang R, Zhang L, et al. Apically extruded debris and irrigant with two Ni-Ti systems and hand files when removing root fillings: a laboratory study. Int Endod J 2013; 46:1125-1130.

21. Berutti E, Chiandussi G, Paolino DS, et al. Effect of canal length and curvature on working length 
alteration with WaveOne reciprocating files. $J$ Endod 2011; 37:1687-1690.

22. Bürklein $S$, Jäger $P G$, Schäfer E. Apical transportation and canal straightening with different continuously tapered rotary file systems in severely curved root canals: F6 SkyTaper and OneShape versus Mtwo. Int Endod J 2017; 50:983 - 90.

23. Bürklein S, Flüch S, Schäfer E. Shaping ability of reciprocating single-file systems in severely curved canals: WaveOne and Reciproc versus WaveOne Gold and Reciproc blue. Odontology 2019; 107:96102 .
24. Üstün Y, Çanakçi BC, Dinçer AN, et al. Evaluation of apically extruded debris associated with several Ni-Ti systems. Int Endod J 2015; 48:701-704.

25. Arslan H, Doğanay E, Alsancak $M$, et al. Comparison of apically extruded debris after root canal instrumentation using Reciproc instruments with various kinematics. Int Endod J 2016; 49:307310.

26. Boijink D, Costa DD, Hoppe CB, et al. Apically Extruded Debris in Curved Root Canals Using the WaveOne Gold Reciprocating and Twisted File Adaptive Systems. J Endod 2018; 44:1289-1292. 